\title{
MMP3 activity rather than cortical stiffness determines NHE1-dependent invasiveness of melanoma cells
}

Dennis Keurhorst ${ }^{1}$, Ivan Liashkovich¹, Fabian Frontzek², Svenja Nitzlaff ${ }^{3}$, Verena Hofschröer ${ }^{1}$, Rita Dreier ${ }^{4}$ and Christian Stock ${ }^{1,5^{*}}$ (D)

\begin{abstract}
Background: Both cell adhesion and matrix metalloproteinase (MMP) activity depend on $\mathrm{pH}$ at the cell surface. By regulating extracellular juxtamembrane $\mathrm{pH}$, the $\mathrm{Na}^{+} / \mathrm{H}^{+}$exchanger NHE1 plays a significant part in human melanoma (MV3) cell migration and invasion. Because NHE1, besides its pH-regulatory transport function, also serves as a structural element tying the cortical actin cytoskeleton to the plasma membrane, we investigated whether NHE1 affects cortical stiffness of MV3 cells, and how this makes an impact on their invasiveness.
\end{abstract}

Methods: NHE1 overexpressing MV3 cells were compared to the corresponding mock-transfected control cells. NHE1 expression was verified by Western blotting, cariporide (HOE642) was used to inhibit NHE1 activity, cell stiffness was determined by atomic force microscopy, and F-actin was visualized by phalloidin-staining. Migration on, and invasion of, native and glutaraldehyde-fixed collagen I substrates were analyzed using time-lapse video microscopy and Boyden-chamber assays, respectively. MMP secretion and activity were detected by Western blot and zymography, respectively. MMP activity was inhibited with NNGH.

Results: The cortical, but not the bulk stiffness, was significantly higher in NHE1 overexpressing cells. This increase in cortical stiffness was accompanied by a reorganization of the cortical cytoskeleton, i.e. a condensation of F-actin underneath and along the plasma membrane. However, it was not affected by NHE1 inhibition. Nevertheless, actin dynamics is required for cell invasion as demonstrated with the application of cytochalasin D. NHE1 overexpression was associated with an elevated MMP3 secretion and an increase in the invasion of a native matrix. This increase in invasiveness could be antagonized by the MMP inhibitor NNGH. Transmigration through a glutaraldehyde-fixed, indigestible substrate was not affected by NHE1 overexpression.

Conclusion: NHE1, as a structural element and independently of its transport activity, contributes to the organization of the cortical F-actin meshwork and thus impacts cortical stiffness. Since NHE1 overexpression stimulates MMP3 secretion but does not change transmigration through a fixed substrate, MV3 cell invasion of a native substrate depends on MMP activity rather than on a modifiable cortical stiffness.

Keywords: Cell migration, (Cortical) cell stiffness, Matrix digestion, Metastasis, pH

\footnotetext{
*Correspondence: Stock.Christian@mh-hannover.de

${ }^{5}$ Department of Gastroenterology, Hannover Medical School,

Carl-Neuberg-Str. 1, 30625 Hannover, Germany

Full list of author information is available at the end of the article
} 


\section{Background}

Upregulation of the expression/activity of the ubiquitously expressed acid-extruding membrane transporter NHE1 $\left(\mathrm{Na}^{+} / \mathrm{H}^{+}\right.$exchanger 1$)$ has been commonly correlated with tumor malignancy [1]. NHE1, by taking advantage of the inwardly directed $\mathrm{Na}^{+}$-gradient across the plasma membrane, exchanges one $\mathrm{H}^{+}$for one $\mathrm{Na}^{+}$ and thus contributes significantly to cellular $\mathrm{pH}$ homeostasis [2]. A higher basal NHE1 activity is characteristic of tumor cells. It often leads to an increase in cytosolic steady state $\mathrm{pH}_{\mathrm{i}}$, and an alkaline $\mathrm{pH}_{\mathrm{i}}$ favors (aerobic) glycolytic metabolism [3, 4], proliferation and evasion of apoptosis [5]. The resulting decrease in extracellular $\mathrm{pH}$ $\left(\mathrm{pH}_{\mathrm{e}}\right)$, especially when accompanied by local intracellular alkalization [6], promotes tumor cell migration and invasion [7]. The intracellular $\mathrm{pH}$ affects cytoskeletal dynamics while the $\mathrm{pH}$ at the cell surface modulates cell/matrix interactions and stimulates the activity of matrix metalloproteinases (MMPs) [8]. Thus, by regulating $\mathrm{pH}_{\mathrm{i}}$ and $\mathrm{pH}_{\mathrm{e}}$, NHE1 activity has a significant effect on the three major variables underlying cell motility: (i) MMPs clearing the way through the extracellular matrix, (ii) focal adhesion complexes ensuring a well-balanced substrate grip, and (iii) the cytoskeletal machinery including actomyosin dynamics considered as the engine for cell migration.

In addition to its $\mathrm{pH}$ - and osmoregulatory transport function, NHE1 (i) operates as a plasma membrane scaffold in the assembly of signaling complexes and (ii) serves as a structural anchor for actin filaments through its direct binding of actin binding proteins of the ezrin, radixin and moesin (ERM) family [9]. As an actin anchoring protein, NHE1 maintains the cell shape by tying the plasma membrane to cortical actin filaments [10]. $\mathrm{H}^{+}$ export and actin anchoring, both mediated by NHE1, dynamically coordinate the remodeling of actin and cellsubstrate adhesion, which considerably contributes to cell motility [11].

The concerted action of actin and its accessory and regulatory proteins such as non-muscle myosin II is required not only for cell migration and invasion, but also for defining and modulating the cell shape [12]. Accordingly, the cortical actin-myosin network, located right underneath the plasma membrane, determines the mechanical properties of the cell surface. Structure, density and integrity of the cortical actin meshwork determine cortical elasticity or stiffness [13] and can be affected by various parameters including the plasma membrane potential [14].

Local rupture or regulated tapering of the cortical actin network can lead to the formation of blebs. Usually, extensive blebbing indicates apoptosis, but the formation of blebs can also be characteristic of an amoeboid mode of cell migration, particularly of an invasive behavior in a spatially constrained environment $[15,16]$. In this setting, blebs seem to be advantageous and replace lamellipodia and other protruding structures [17]. Consistently with the occurrence of blebbing due to local changes in the cortical actin network during amoeboid movement in a dense extracellular matrix network, the stiffness of both tumor cells obtained from patients and cancer cell lines has been shown to inversely correlate with the invasion of three-dimensional basement membranes. Cancer cells with the lowest invasive potential are five times stiffer than those with the highest invasive potential [18]. This holds true also for ovarian cancer cells that are generally softer than non-malignant ovarian epithelial cells [19] and for cancerous human bladder cells [20].

As NHE1 is able to tie the cortical actin to the membrane, and the integrity of the cortical actin network affects stiffness, blebbing and invasiveness, the present study aims to investigate a possible relationship between NHE1 expression, cell stiffness and invasiveness.

\section{Material and methods Cell culture}

Human melanoma cells of the MV3 cell line [21], stably transfected with an empty pcDNA3 vector (control) or with the pcDNA3 vector carrying NHE1 (NHE1 overexpressing; [22]), were grown in bicarbonate buffered Roswell Park Memorial Institute (RPMI) 1640 medium (Sigma, Taufkirchen, Germany) supplemented with $10 \%(v / v)$ fetal calf serum (FCS) at $37{ }^{\circ} \mathrm{C}$ in a humidified atmosphere of $5 \% \mathrm{CO}_{2}, 95 \%$ air. The culture medium contained $0.6 \mathrm{~g} \mathrm{l}^{-1}$ geneticin (G-418-sulfate; PAA Laboratories, Pasching, Austria) in order to select the transfected cells.

\section{Detection of NHE1 and MMP3 by Western blot NHE1}

Confluent cell cultures were washed with cold Dulbecco's phosphate-buffered saline (PBS w/o $\mathrm{Ca}^{2+}, \mathrm{Mg}^{2+}$; Sigma-Aldrich) and lysed at $4{ }^{\circ} \mathrm{C}$ in radioimmunoprecipitation assay (RIPA) lysis buffer $\left(150 \mathrm{mmol} \mathrm{l}^{-1} \mathrm{NaCl}\right.$, $25 \mathrm{mmol} \mathrm{l}^{-1}$ Tris $\mathrm{HCl}$ (pH 7.6), $1 \%$ Nonidet P-40, $0.1 \%$ SDS, $1.0 \%$ sodium deoxycholate, a protease and a phosphatase inhibitor cocktail (cOmplete, Mini; PhosSTOP; both from Roche)). Lysates were scraped off and spun down at $13,000 \times g$ and $4{ }^{\circ} \mathrm{C}$ for $10 \mathrm{~min}$. Protein concentrations were determined with the Bicinchoninic Acid Protein Assay Kit (Thermo Scientific). Equal amounts of protein $(\sim 30 \mu \mathrm{g})$ mixed with sample buffer $(4: 1(v / v)$; $500 \mathrm{mmol} \mathrm{l}^{-1}$ Tris, $100 \mathrm{mmol}^{-1}$ dithiothreitol, 8.5\% SDS, $27.5 \%$ sucrose, and $0.03 \%$ bromphenol blue indicator) were loaded, separated by SDS-PAGE (7.5\% acrylamide gels; Minigel System, Bio-Rad Laboratories) and transferred onto polyvinylidene difluoride (PVDF) membranes 
(Immobilon Transfer Membranes, Millipore) by tank blotting at $4{ }^{\circ} \mathrm{C}$ overnight. PVDF membranes carrying the blotted proteins were immersed in $5 \%(\mathrm{w} / \mathrm{v})$ skim milk in $0.05 \%(\mathrm{v} / \mathrm{v})$ Tween in PBS Dulbecco (w/o $\mathrm{Mg}^{2+}$; Biochrom AG) for $30 \mathrm{~min}$ at room temperature followed by overnight incubation with the primary antibody against NHE1 (mouse, 1:1000 in 5\% skim milk/0.05\% PBS-T; BD Biosciences). After washing $(3 \times 10 \mathrm{~min}$ in $0.05 \%$ Tween in PBS), blots were incubated for $1 \mathrm{~h}$ with a peroxidase (POD)-conjugated secondary antibody (goat anti-mouse POD, $1: 25,000$ in $5 \%$ skim milk/0.05\% PBS-T, Dianova) and then washed again $(3 \times 10 \mathrm{~min}$ in $0.05 \%$ Tween in PBS). Blots were developed using a chemiluminescence kit (SuperSignal West Femto Maximum Sensitivity Substrate, Thermo Scientific). Autoluminography was carried out with a ChemiDoc XRS gel documentation system and Quantity-One analysis software (Bio-Rad Laboratories). To control protein loading, membranes were stripped and then probed with a monoclonal anti- $\beta$-actin antibody (anti-mouse, 1:10,000; Sigma Life Science; secondary antibody 1:25,000 (goat anti-mouse POD, Dianova)). The Quantity-One software (Bio-Rad) was applied for densitometric analyses. The protein amount was normalized to the amount of $\beta$-actin.

\section{MMP3}

Confluent cell cultures were thoroughly washed with PBS (Dulbecco, Biochrom AG) and then kept in serum-free, G418-containing RPMI 1640 medium for $24 \mathrm{~h}$. In order to inhibit NHE1 activity, cariporide (HOE642; Santa Cruz Biotechnology; final concentration $10 \mu \mathrm{mol} \mathrm{l}^{-1}$ ) was added and renewed after $12 \mathrm{~h}$. After $24 \mathrm{~h}, 1 \mathrm{ml}$ of the MMP-containing medium was used for trichloroacetic acid (TCA) precipitation. After adding $225 \mu \mathrm{l} 60 \%$ TCA (final concentration $12 \%$ ) and $139 \mu \mathrm{l}$ 1\%Triton (final concentration $\sim 0.1 \%)$, the medium was vortexed and incubated on ice for $20 \mathrm{~min}$. The precipitate was spun down at $14,000 \mathrm{rpm}, 4{ }^{\circ} \mathrm{C}$ for $20 \mathrm{~min}$, and washed twice with $\mathrm{EtOH}$ for $30 \mathrm{~min}$. Each washing step was followed by 20 min centrifugation. Finally, the pellet was rinsed with ice cold acetone, centrifuged for $20 \mathrm{~min}$, dried at $37^{\circ} \mathrm{C}$, resuspended and vortexed in sample buffer (2\% SDS, $10 \%$ Glycerol, $60 \mathrm{mmol} \mathrm{l}^{-1}$ Tris-HCl (pH6.8), 0.001\% bromophenol blue, $5 \% \beta$-mercaptoethanol), and then heated to $95{ }^{\circ} \mathrm{C}$ for $5 \mathrm{~min} .40 \mu \mathrm{l}$ samples were subjected to electrophoresis in 4.5-15\% SDS-polyacrylamide gradient-gels run at $30 \mathrm{~mA}$. The separated proteins were electrotransferred to a nitrocellulose membrane (Protran nitrocellulose transfer membrane, BA 83, $0.2 \mu \mathrm{m}$, Whatman plc) at a constant current of $80 \mathrm{~mA}$ for $3 \mathrm{~h}$ at $4{ }^{\circ} \mathrm{C}$. Total protein detection served as a loading control and was performed using the Pierce MemCode ${ }^{\mathrm{TM}}$ reversible protein stain kit (Pierce Biotechnology Inc.). The nitrocellulose membrane was destained using the MemCode stain eraser. Unspecific binding sites were blocked with Tris-buffered saline (TBS-T: $50 \mathrm{mmol} \mathrm{l}^{-1}$ Tris/HCl (pH7,4), $150 \mathrm{mmol} \mathrm{l}^{-1}$ $\mathrm{NaCl}, 0.05 \%$ Tween-20) containing 5\% skim milk and $1 \%$ bovine serum albumin for $1 \mathrm{~h}$ at room temperature. The nitrocellulose membrane was then incubated with a primary antibody against MMP3 (monoclonal from rabbit (Abcam), 1:1000 in TBS-T containing 2.5\% skim milk and $0.5 \%$ BSA) at $4{ }^{\circ} \mathrm{C}$ overnight. The nitrocellulose membrane was rinsed with TBS-T $(3 \times 15 \mathrm{~min})$ followed by $1 \mathrm{~h}$ incubation with the secondary, horseradish peroxidase-conjugated antibody (donkey anti-rabbit (Amersham BioSciences), 1:10,000 in TBS-T with $2.5 \%$ skim milk and $0.5 \% \mathrm{BSA}$ ) at room temperature. After washing with TBS-T $(3 \times)$, the membrane was developed employing the SuperSignal West Femto Maximum Substrate (Thermo Fisher Scientific). Detection of labeled protein bands was performed with a chemiluminescence imaging system (Fusion SL4.2P, Vilber Lourmat).

\section{Actin staining}

Cells were seeded onto collagen type I-coated (Collagen G, Biochrom AG; final concentration $0.4 \mathrm{mg} \mathrm{ml}^{-1}$ ) coverslips and cultured for $2 \mathrm{~h}$. The cells were then fixed with $3.5 \%$ paraformaldehyde $(w / v)$ in PBS (Dulbecco, Biochrom AG) for $30 \mathrm{~min}$ and permeabilized for $25 \mathrm{~min}$ in $0.1 \%(v / v)$ Triton X-100/TBS in order to ensure that the intracellular F-actin epitopes were accessible to the antibody. After washing with PBS $(2 \times)$, nonspecific binding sites were blocked with $3 \%$ bovine serum albumin (BSA) in PBS $(w / v)$ for $2 \mathrm{~h}$ at room temperature. The cells were then stained with Alexa Fluor ${ }^{\circledR} 488$ Phalloidin (Invitrogen AG; dilution 1:100) for 45 min. Prior to Dako mounting (Dako A/S, Glostrup, Denmark), the cells were washed in PBS once again. Images were taken with a digital camera (Model 9.0, RT-SE-Spot, Visitron Systems, Puchheim, Germany) fitted to an inverted microscope (Axiovert 200, Carl Zeiss AG) and controlled by MetaVue software (Visitron Systems).

\section{Measuring cell stiffness by atomic force microscopy (AFM)} Employing a JPK NanoWizard 3 (JPK Instruments, Berlin, Germany) combined with a Leica DMI 6000 (CS Trino AFC) inverted fluorescence microscope (Leica Microsystems GmbH, Wetzlar, Germany) and the JPK SPM software (JPK Instruments) both the cortical and the bulk stiffness of the two MV3 clones were measured. To this end MV3 cells were seeded onto collagen type I (Collagen G, Biochrom AG)-coated glass bottom dishes (35 $\mathrm{mm}$ in diameter, WillCo Wells) at a density corresponding to $70 \%$ confluency and were kept in HEPES buffer $\left(122.5 \mathrm{mmol} \mathrm{l}^{-1} \mathrm{NaCl}, 5.4 \mathrm{mmol} \mathrm{l}^{-1} \mathrm{KCl}\right.$, $0.8 \mathrm{mmol} \mathrm{l}^{-1} \mathrm{MgCl}_{2}, 1.2 \mathrm{mmol} \mathrm{l}^{-1} \mathrm{CaCl}_{2}, 5.5 \mathrm{mmol} \mathrm{l}^{-1}$ 
glucose, 10.0 mmol $~^{-1}$ HEPES; pH 7.4) at $37{ }^{\circ} \mathrm{C}$ in a heated chamber mounted on the stage of the microscope. For the AFM-measurements a soft cantilever (nominal spring constant $=0.03 \mathrm{~N} \mathrm{~m}^{-1}$, Novascan Technologies) with a spherical tip (sphere diameter $=10 \mu \mathrm{m}$ ) and a maximum loading force of approximately $1 \mathrm{nN}$ were used.

Essential mechanical probing parameters including deflection sensitivity and cantilever spring constant were calibrated prior to each experiment. Cell stiffness was chosen as a preferred quantitative readout of mechanical alteration of the cells. The stiffness value provides the most direct and straightforward mechanical readout for a given combination of an AFM probe and a sample. On the other hand, such precise calculation of the elastic modulus relies heavily on several additional parameters [23] which could not be obtained during our experiments. Cell nanoindentation was performed by applying a maximal loading force of $1 \mathrm{nN}$ at a loading rate of $1 \mu \mathrm{m} \mathrm{s}^{-1}$. Resulting cell deformation was used to calculate the cell stiffness as described previously [24].

\section{Preparation of collagen matrices for cell migration}

A collagen I substrate was prepared by gently mixing $210 \mu \mathrm{l}$ of $5 \times$ RPMI1640, $210 \mu \mathrm{l}$ of $5 \times$ HEPES-buffer (final concentration in the polymerized collagen gels: $10 \mathrm{mmol} \mathrm{l}^{-1}$ ), $245 \mu \mathrm{l}$ of distilled water and $430 \mu \mathrm{l}$ of Collagen $\mathrm{G}$ (containing acid-soluble calfskin collagen type I at a concentration of $\sim 4 \mathrm{mg} \mathrm{ml}^{-1}$ ). The $\mathrm{pH}$ value of the mixture was adjusted to 7.4 with $1 \mathrm{M} \mathrm{NaOH}$. A thin layer $(\sim 200 \mu \mathrm{l})$ of this collagen I matrix polymerized on the bottom of a $12.5 \mathrm{~cm}^{2}$ culture flask (Falcon, Corning Inc.) in a humidified atmosphere at $37^{\circ} \mathrm{C}$ overnight. The next day, the cells were seeded onto this matrix and allowed to attach and spread for $6 \mathrm{~h}$.

In one set of experiments matrix metalloprotease (MMP) activity was disabled by fixing the matrix with $2 \mathrm{ml}$ of $2 \%$ glutaraldehyde in PBS $(v / v)$ for $15 \mathrm{~min}$. The matrix was washed $(5 \times 5 \mathrm{~min})$ with $\mathrm{PBS}$ and stored in PBS at $4{ }^{\circ} \mathrm{C}$ overnight. The next day, the fixed matrix was washed again $(5 \times 5 \mathrm{~min}$ PBS $)$ and the cells were seeded.

\section{Cell migration}

The culture flasks were placed in heated chambers $\left(37^{\circ}\right)$ on stages of inverted microscopes (Axioverts $40 \mathrm{C}$ and 20, Carl Zeiss AG). Employing video cameras (Model XC-ST70CE and XC-77CE; Hamamatsu/Sony) and PCvision frame grabber boards (Hamamatsu) cell migration was recorded in $10 \mathrm{~min}$ intervals for $5 \mathrm{~h}$. Images were acquired with HiPic and WASABI software (Hamamatsu), and cell contours were labeled applying AMIRA software (TGS, Template Graphics Software, Mercury Communication System Inc.). From these contours the migration velocity $\left(\mu \mathrm{m} \mathrm{min}{ }^{-1}\right)$, translocation $(\mu \mathrm{m})$, total distance covered $(\mu \mathrm{m})$, cell area $\left(\mu \mathrm{m}^{2}\right)$ and the structural index (SI) were analyzed using the NIH ImageJ software and self-made Java programs [25]. Migratory speed was determined from the movement of the cell center, translocation corresponds to the linear or net distance covered, and SI represents the morphological cell shape. SI was calculated according to the formula $\mathrm{SI}=(4 \pi A) / p^{2}$, where $p$ represents the perimeter of the area $A$ covered by the cell. A spherical cell is represented by values close to 1 , a dendritic cell shape by values close to 0 . A directionality index (di) was calculated as:

$$
d i=\frac{\text { linear distance covered }(\mu \mathrm{m})}{\text { mean velocity }(\mu \mathrm{m} / \mathrm{min}) \times \text { total duration }(\mathrm{min})} .
$$

\section{Invasion-transmigration}

Transmigration was determined employing Boyden chamber assays. $20 \mu \mathrm{l}$ of the collagen I mixture (composition as described above) were allowed to polymerize on a filter-membrane (insert for a 24 well plate, $8.0 \mu \mathrm{m}$ pore size; ThinCert, Greiner Bio-One $\mathrm{GmbH}$ ) at $37{ }^{\circ} \mathrm{C}$ in a humidified atmosphere overnight. 200,000 cells per filter were seeded onto this collagen matrix. After $24 \mathrm{~h}$ incubation in RPMI1640 with G-418 and serum, the medium was gently renewed for another $24 \mathrm{~h}$. Cells were then fixed and stained with crystal violet (Sigma-Aldrich) in PBS. The matrix and the remaining cells on the upper side of the filter were removed and excess crystal violet was washed away with PBS. The invasive cells that remained on the lower side of the filter and those on the bottom of the well were counted.

MMP activity was inhibited by $10 \mu \mathrm{mol} \mathrm{l^{-1 }} \mathrm{NNGH}$ ( $N$-isobutyl- $N$-(4-methoxyphenylsulfonyl)glycyl hydroxamic acid; Sigma-Aldrich), and NHE1 was inhibited with $10 \mathrm{\mu mol} \mathrm{l}^{-1}$ cariporide (HOE642). DMSO, the solvent for NNGH and cariporide, reached a final concentration of $0.1 \%$.

Total MMP activity was disabled by fixing the matrix with $1 \mathrm{ml}$ of $2 \%$ glutaraldehyde in PBS $(v / v)$ for $15 \mathrm{~min}$. In order to ascertain the role of actin in transmigration through a fixed matrix, cells were exposed to Cytochalasin $\mathrm{D}\left(50 \mathrm{nmol}^{-1}\right)$ over the entire experiment $(48 \mathrm{~h})$.

\section{Matrix digestion in situ}

$20 \mu \mathrm{l}$ of the collagen mixture (see above) were allowed to polymerize on coverslips ( $\varnothing 15 \mathrm{~mm}, \mathrm{R}$. Langenbrinck $\mathrm{GmbH}$, Germany) for at least $3 \mathrm{~h}$ in a humidified atmosphere $\left(5 \% \mathrm{CO}_{2}, 95 \%\right.$ air $)$ at $37^{\circ} \mathrm{C}$. The matrices were then either kept in PBS at $4{ }^{\circ} \mathrm{C}$ until use, or they were fixed with $2 \%$ glutaraldehyde in PBS $(v / v)$ for 15 min, washed $(5 \times 5 \mathrm{~min})$ with $\mathrm{PBS}$ and stored in PBS at $4{ }^{\circ} \mathrm{C}$ overnight. The next day, the fixed collagen substrates were 
washed again $(5 \times 5$ min PBS), and cells were seeded onto the fixed and the native matrices. The medium was renewed after $24 \mathrm{~h}$. After $48 \mathrm{~h}$ the cells on the native matrix were fixed with $2 \%$ glutaraldehyde in PBS $(v / v)$ for $15 \mathrm{~min}$ and then washed with PBS $(5 \times 5 \mathrm{~min})$. The coverslips carrying the cells were mounted on glass slides with fluorescence mounting medium containing DAPI (4',6-diamidino-2-phenylindol; Dako A/S, Glostrup, Denmark). The glutaraldehyde-induced autofluorescence of the collagen substrate (at $488 \mathrm{~nm}$ ) was evaluated employing the same setup as that used for the actin staining. The NIH ImageJ software (http://rsb.info.nih.gov/ ij/) was used to determine the fluorescence intensity per visual field (233.086 pixels).

\section{Zymography}

$20 \mu \mathrm{l}$ of conditioned media from confluent cell cultures were mixed with equal volumes $(20 \mu \mathrm{l})$ of twofold concentrated sample loading buffer $\left(2 \mathrm{mmol} \mathrm{l}^{-1}\right.$ EDTA, 2\% SDS, $20 \%$ glycerol, $0.02 \%$ bromophenol blue, $20 \mathrm{mmol} \mathrm{l}^{-1}$ Tris/ $\mathrm{HCl}, \mathrm{pH} 8.0)$ and subjected to electrophoresis on a $1 \%$ gelatin-(porcine skin, Sigma-Aldrich) containing $4.5-15 \%$ gradient SDS-polyacrylamide gel run at $40 \mathrm{~mA}$. The gel was washed twice for $30 \mathrm{~min}$ in $2.5 \%$ Triton$\mathrm{X} 100$, rinsed in distilled water and then developed in $50 \mathrm{mmol} \mathrm{l}^{-1}$ Tris/ $\mathrm{HCl}\left(\mathrm{pH}\right.$ 8.5) containing $5 \mathrm{mmol} \mathrm{l}^{-1}$ $\mathrm{CaCl}_{2}$ overnight at $37 \%$. It was stained with Coomassie brilliant blue R250 (0.15\% Coomassie BB R-250; Bio-Rad Laboratories).

\section{Statistics}

Data are presented as the mean values \pm SEM. Depending on the experiment type experiments were repeated three up to nine times. Significance of the data was determined with the student's unpaired or paired $\mathrm{t}$ test. $p<0.05$ was set as the level of significance (" $\mathrm{p}<0.05$; *** $\left.\mathrm{p}<0.01 ;{ }^{* * * *} \mathrm{p}<0.001\right)$.

\section{Results}

\section{Expression of NHE1}

Differences in the expression of NHE1 in control (empty vector) and NHE1 overexpressing MV3 cells, previously generated by Frontzek et al. (2014), were checked by Western blot (Fig. 1). The expression of both, the glycosylated NHE1 molecule $(\sim 110 \mathrm{kDa})$ and the NHE1 precursor $(\sim 85 \mathrm{kDa})$, was clearly increased in NHE1 overexpressing cells.

\section{Cortical stiffness depends on NHE1 expression}

NHE1 is bound to the cortical actin cytoskeleton by adaptor proteins such as members of the ERM family [26]. Hence, the question arises as to whether or not the cortical cell stiffness might be affected by the presence

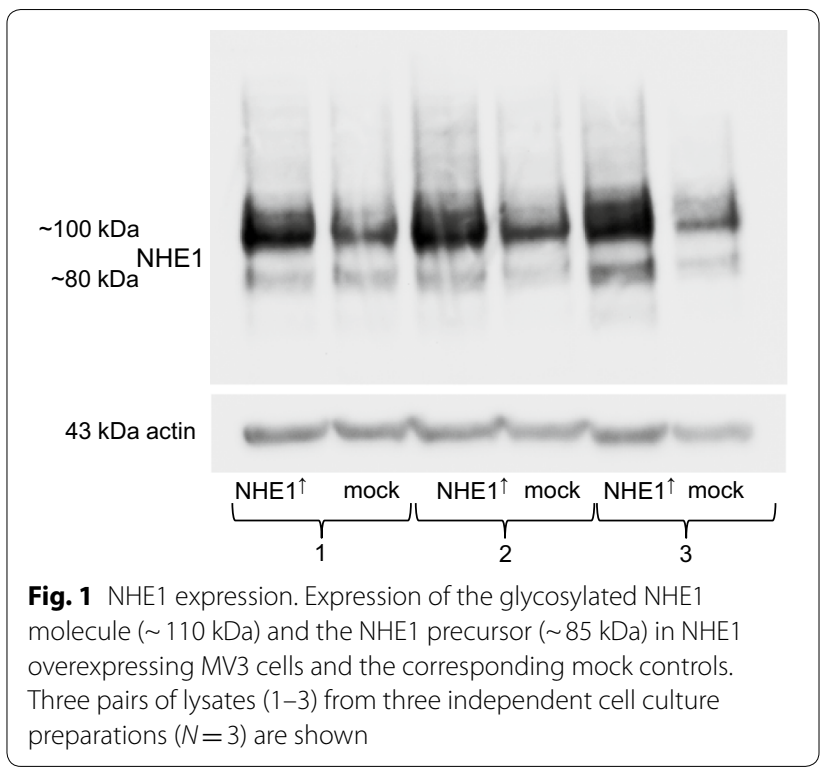

and/or activity of NHE1. By employing AFM the cortical and the bulk stiffness of MV3 cells were determined. The cortical stiffness was significantly higher in NHE1 overexpressing than in control cells whereas the bulk stiffness did not differ (Fig. 2a). Neither the cortical nor the bulk stiffness were substantially decreased when NHE1 activity was inhibited by cariporide (HOE642) (Fig. 2b) indicating that the mere presence of NHE1 as a structural element has an impact, independently of its ion transport function. However, there was a significant difference in cortical stiffness between cells treated with cariporide and those exposed to DMSO as the solvent for cariporide, suggesting that DMSO alone may have an effect on the cortical stiffness.

\section{NHE1 expression affects F-actin}

The finding that NHE1 overexpressing cells show a higher cortical stiffness prompted us to visualize cortical F-actin by phalloidin staining. Indeed, NHE1 overexpression was associated with a rearrangement of cortical F-actin (Fig. 3). Whether seeded on glass, a native or a glutaraldehyde-fixed collagen type I matrix, NHE1 overexpressing cells always showed a higher cortical actin density and less stress fibers than the empty vector controls. The F-actin appeared as a belt-like structure, possibly forming a thick layer of cortical F-actin at the expense of stress-fibers. In addition, NHE1 overexpression caused the formation of spike-like structures at the cell surface and an annular arrangement of the F-actin (Fig. 3b, d, f). This observation suggests a positive correlation between the NHE1 expression level, the annular arrangement of cortical F-actin and the strength of the cortical actin skeleton. 

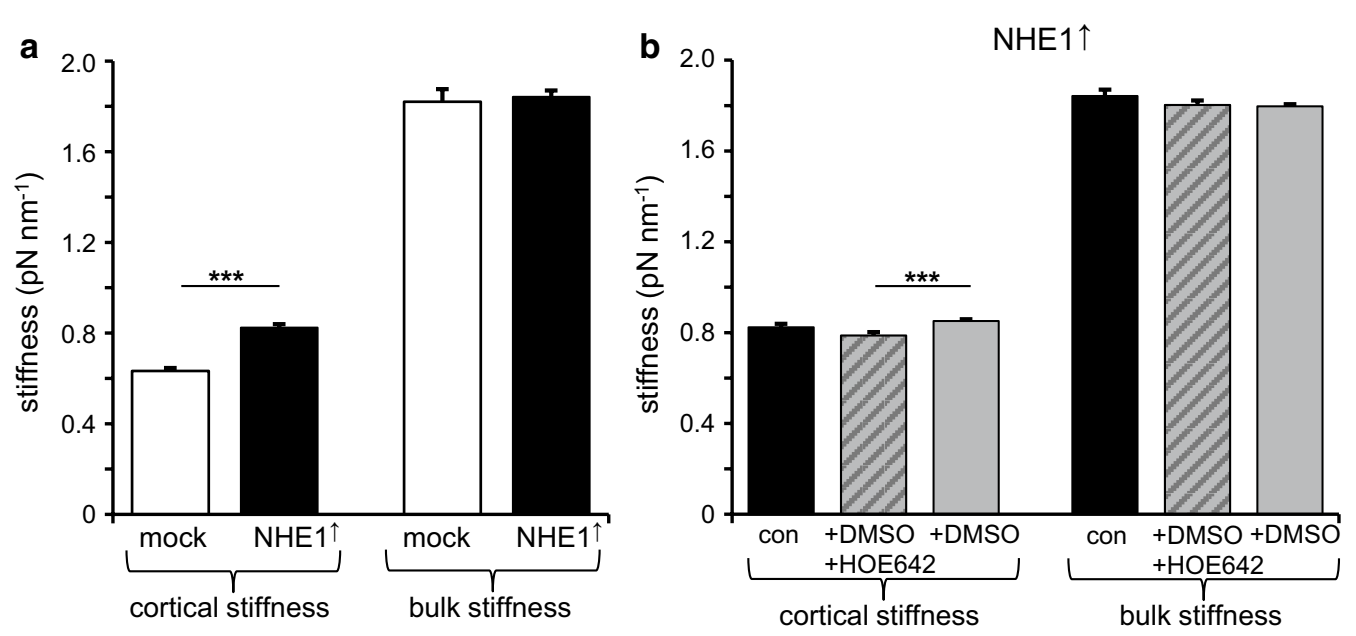

Fig. 2 Cortical stiffness depends on NHE1 expression. a The cortical stiffness of NHE1 overexpressing MV3 cells ( $n=123$ cells from N=4 independent experiments) is significantly higher than that of the mock controls $(n=141, N=3)$ while the bulk stiffness is not affected ( $n=119$, $N=4$ for NHE1 overexpressing cells; $n=143, N=3$ for empty vector controls). $\mathbf{b}$ The bulk stiffness of NHE1 overexpressing MV3 cells is not affected by NHE1 inhibition with cariporide (HOE642). Although there is no difference in cortical stiffness between entirely untreated $(n=119, N=4)$ and cariporide treated $(n=93, N=3$ ) cells, a slight, yet significant difference can be observed between cells treated with the solvent DMSO alone $(n=144, N=3)$ and those treated with cariporide dissolved in DMSO

\section{NHE1 expression affects matrix digestion}

Since the activity of NHE1 has been shown to favor MMP-mediated ECM-digestion and thus invasion [27], mock-control and NHE1 overexpressing cells were compared regarding their digestive activity on a native and a glutaraldehyde-fixed reconstituted collagen matrix. The glutaraldehyde-induced autofluorescence was taken advantage of in order to identify low-matrix or matrixfree regions that represent MMP activity. While there was no noteworthy ECM-digestion on the fixed matrix, NHE1 overexpressing cells digested significantly more $(\sim 16 \%)$ of the native matrix than the mock-control cells (Fig. 4).

\section{NHE1 overexpression reduces cell migration on fixed collagen type I}

Since the protons extruded by NHE1 are known to finetune the interplay between formation and release of focal adhesion contacts as required for cell migration $[6,28]$, we compared the migratory behavior of mock-control and NHE1 overexpressing cells on a fixed and a native collagen (type I) substrate (Fig. 5, Table 1). In control cells, substrate fixation did not cause changes in migratory speed (Table $1, p=0.37)$, net distance $(p=0.75)$ total distance covered within $5 \mathrm{~h}(p=0.37)$, and directionality $(p=0.24)$. In NHE1 overexpressing cells, however, matrix fixation led to significant decreases in all of the observed parameters [migratory speed $\left(p<10^{-15}\right)$, net distance $\left(p<10^{-6}\right)$, total distance $\left(p<10^{-15}\right)$, and directionality $(p=0.004)]$. Comparing control and NHE1 overexpressing cells reveals, that on both, the native and the fixed collagen substrate, NHE1 overexpressing cells migrate significantly more slowly (native matrix: $p=0.006$; fixed matrix: $p<10^{-15}$ ) and generally cover shorter distances (net and total distance on native (net: $p=0.106$; total: $p=0.006$ ) and fixed matrix (net: $\mathrm{p}<10^{-6}$; total: $\left.p<10^{-15}\right)$, respectively), while the directionality is hardly affected. The observed decrease in migratory activity could be caused by either an excessive or by an insufficient interaction between cell surface and substrate. In order to find out more about the possible reasons we analyzed the cells' morphology.

To a certain extent, the cell morphological parameters reflect the results obtained from the migration experiments (Fig. 6, Table 1). On both, the native and the fixed substrate, the NHE1 overexpressing cells were more spherical (Fig. 6a; Structural index (SI)) than the control cells (native: $p=0.003$; fixed: $p<10^{-5}$ ), indicating that a decrease in migratory activity may correlate with less interaction with the matrix and/or a higher intrinsic contractility expressed through the higher cortical stiffness (Fig. 2) and the F-actin re-arrangement (Fig. 3). On the other hand, although modulating the interaction with the extracellular matrix should be more difficult on a fixed than a native substrate, cells on the fixed substrate displayed a significantly lower SI $\left(p=0.003\right.$ and $p<10^{-4}$ for overexpressing and control cells, respectively) and tended to cover a larger area (Fig. 6b, Table $1 ; p=0.232$ and $p=0.006$ for overexpressing and control cells, respectively native). On both matrices, the area did not differ 


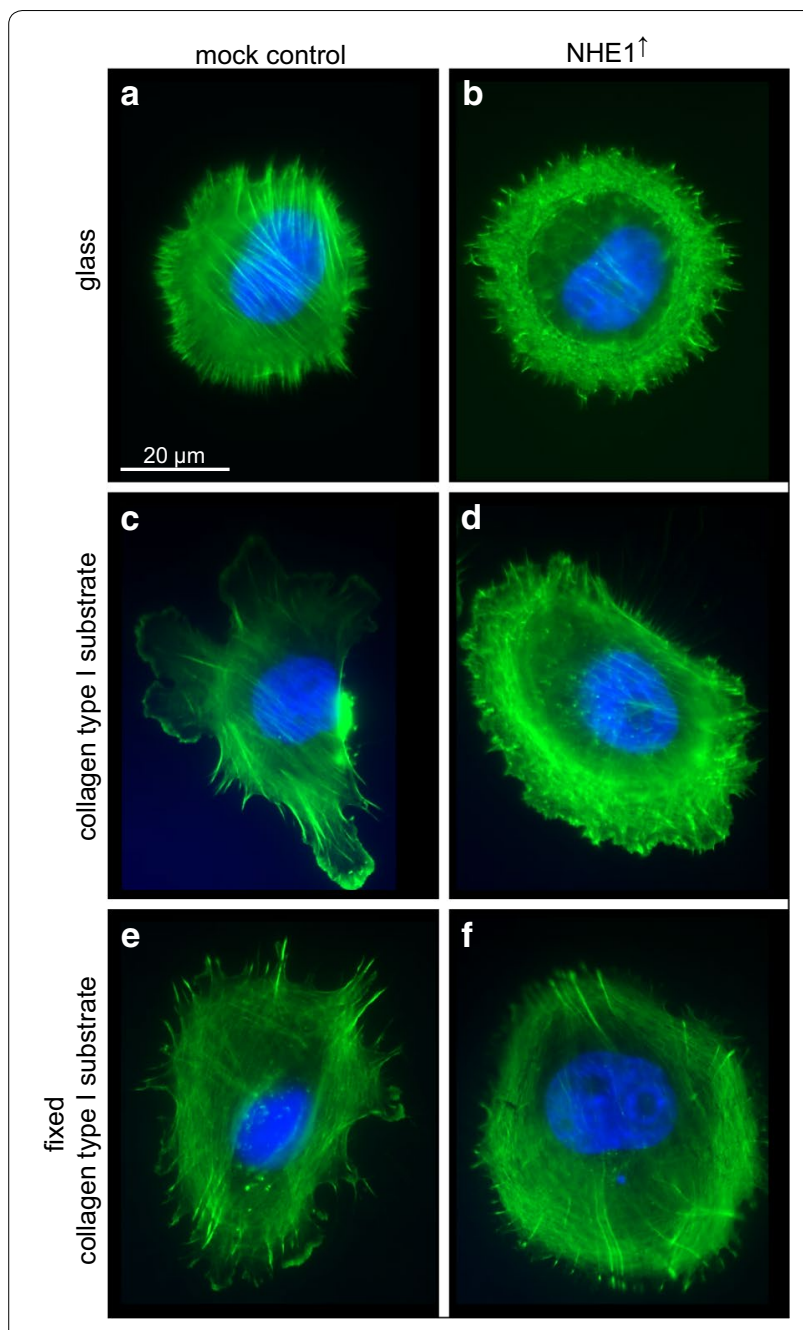

Fig. 3 F-actin arrangement depends on NHE1 expression. Regardless of whether MV3 cells were seeded on glass (a, b), collagen type I (c, d) or a glutaraldehyde-fixed collagen type I substrate (e, f), NHE1 overexpression $(\mathbf{b}, \mathbf{d}, \mathbf{f})$ is accompanied by a rearrangement of $\mathrm{F}$-actin. In addition, the cells surface is characterized by the occurrence of numerous, actin-containing spike-like structures. Actin was labelled with phalloidin. Scale bar: $20 \mu \mathrm{m}$

significantly between NHE1 overexpressing and control cells. Thus, matrix fixation seems to affect cell spreading to a lesser extent than the release of adhesive forces. It is also conceivable that there is a permanent, slightly invasive movement underside, i.e. at the ventral surface of the cells which (i) for technical reasons cannot be observed in 2D experiments such as migration assays on a native substrate and (ii) may not be successful on a fixed substrate. The latter could force the cells to spread and flatten out and thus prevent them from moving deeper into the matrix.

\section{NHE1 overexpression fuels invasion of native collagen type I}

When observed on a native collagen type I substrate in transwell invasion assays, the NHE1 overexpressing cells were considerably more invasive than the control cells (Fig. 7a; $5120 \pm 1533$ vs. $644 \pm 147$ out of originally 200,000 seeded cells transmigrated, $p=0.005$ ). Seeded on a fixed substrate, the invasiveness of both control (138 \pm 52 transmigrated cells) and NHE1 overexpressing cells $(113 \pm 34)$ was strongly reduced while the number of transmigrated cells did not differ $(p=0.66)$. Interestingly, invasion of the fixed substrate did not need NHE1 activity but clearly required actin dynamics, because the NHE1 specific inhibitor cariporide (HOE642) had no effect (131 \pm 66 transmigrated cells), whereas cytochalasin D, a potent inhibitor of actin polymerization, blocked invasion nearly completely ( $5 \pm 2$ invasive cells (Fig. $7 b$ ). In a separate set of experiments, we found that invasion of NHE1 overexpressing cells into the native matrix was reduced by more than $50 \%$ in the presence of $10 \mu \mathrm{mol} \mathrm{l}^{-1}$ of the MMP-inhibitor NNGH (Fig. 8). While the number of transmigrated cells was $300 \pm 86$ in untreated and $248 \pm 71$ in cells exposed to DMSO, the solvent for NNGH, it reached only $115 \pm 22$ in cells treated with the MMP-inhibitor. Taken together, the results of the invasion assays suggest that NHE1 overexpression facilitates MMP-dependent invasion of a native substrate while invasion of a fixed substrate is not affected by NHE1 inhibition but requires actin dynamics.

\section{NHE1 expression stimulates secretion of MMP3}

Since MMPs have been shown to play a major role in NHE1-dependent invasion [27, 29], and because in the present study, the MMP-inhibitor NNGH inhibits invasion of MV3 cells, we assessed the activity of MMPs

\footnotetext{
(See figure on next page.)

Fig. 4 Digestion of collagen type I is fostered by NHE1 expression. a Fluorescence images of MV3 cells on native (upper images) and fixed collagen type I substrate (second row). The lowest image shows a fixed collagen type I substrate without (w/o) cells. Cells were kept on the respective substrate for $48 \mathrm{~h}$ and then fixed with glutaraldehyde. While the fixed substrate is characterized by a network of collagen I fibers the native substrate has been remodeled and mostly digested. Blue: DAPI staining of nuclei; green: glutaraldehyde-induced autofluorescence. Scale bar: $10 \mu \mathrm{m}$. $\mathbf{b}$ Fluorescence intensity measurements of native and fixed matrices. Native matrices populated with NHE1 overexpressing MV3 cells ( $n=49$ areas from $N=4$ independent experiments) show a significantly lower intensity than those with control cells ( $n=25, N=2)$. Regardless of whether being populated with NHE1 overexpressing $(n=40, N=9)$ or control cells $(n=15, N=3)$, the intensities of the fixed substrates did not differ from that of unsettled matrices $(n=18, N=3)$
} 


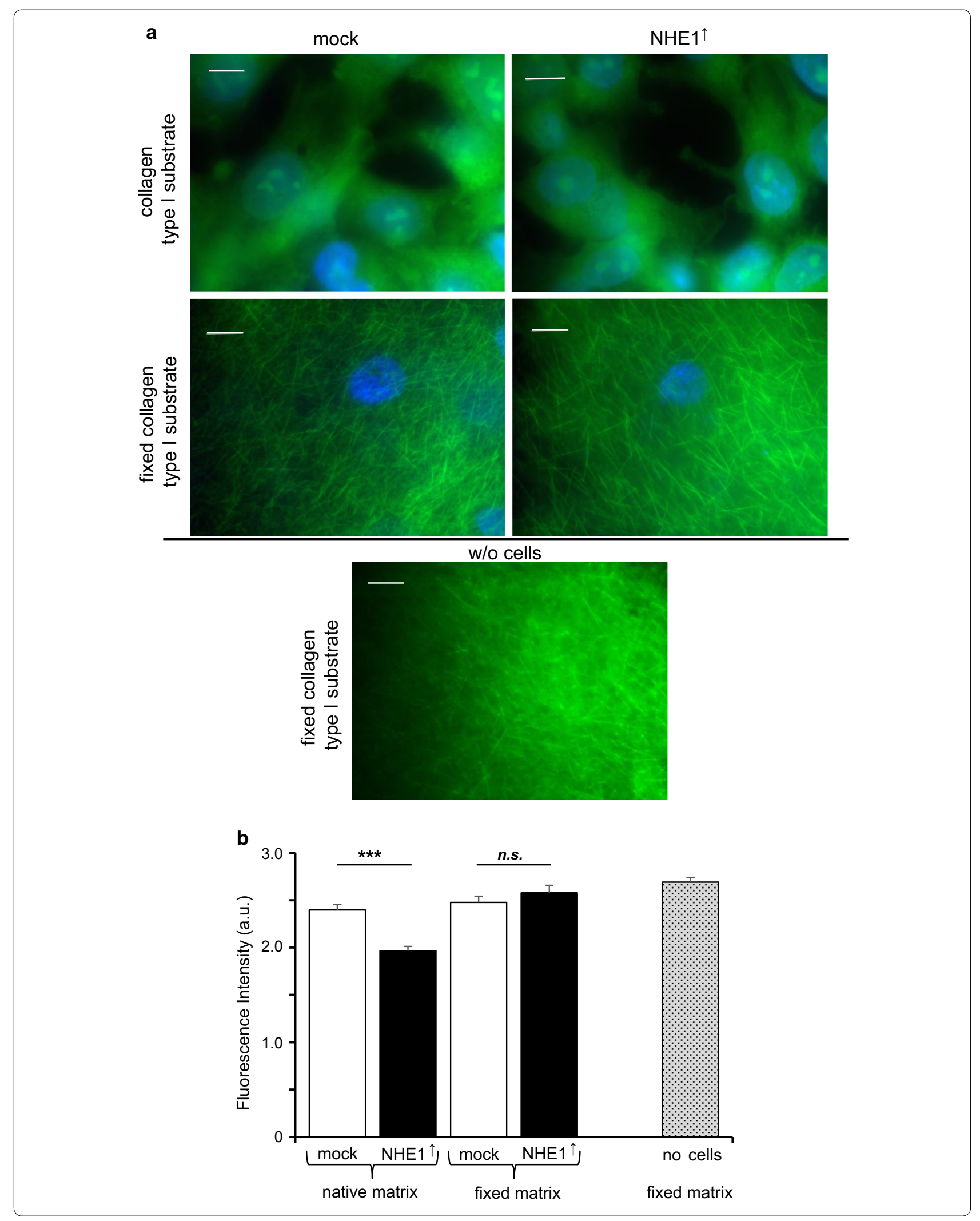


Fig. 5 MV3 cell migration is affected by NHE1 expression and matrix fixation. The effects of NHE1 overexpression become more apparent on a fixed collagen type I substrate. a The migration speed of NHE1 overexpressing cells is significantly lower than that of control cells, on both the native and the fixed substrate. NHE1 overexpressing cells migrate significantly more slowly on the fixed ( $n=41$ cells from $N=3$ independent experiments) than on the native substrate ( $n=40$ cells, $N=3$ ) while control cells do not migrate differently ( $n=33, N=3$ on fixed vs. $n=30, N=5$ on native). $\mathbf{b}$ The net distance covered within $5 \mathrm{~h}$ is lower in NHE1 overexpressing cells with a significant difference on the fixed substrate. NHE1 overexpressing cells cover a shorter distance on the fixed than on the native substrate while the distance covered by control cells does not differ between the two substrates. c NHE1 overexpressing cells cover a lower total distance on both substrates, when compared to the control cells. Compared to the native matrix, NHE1 overexpressing cells cover a lower total distance on the fixed matrix whereas control cells do not show a difference. $\mathbf{d}$ The directionality index does not differ between control and NHE1 overexpressing cells on the native substrate. On the fixed substrate, NHE1 overexpressing cells migrate less directional than control cells on the fixed and NHE1 overexpressing cells on the native substrate

released by the cells into the culture medium by performing zymographic assays. Gelatin degradation assays did not show an NHE1-associated increase in MMP2-, proMMP9- or MMP9-activity (Fig. 9a). Also, casein degradation assays did not show any differences in MMP10activity (data not shown).

Because MMP3 activates the collagenases MMP1, MMP8 and MMP13 [30] that are capable of degrading collagen types I, II, III, V and IX as well as native fibrillary collagen [31] which is crucial for melanoma metastasis, we tested for MMP3 secretion by performing western blot analyses (Fig. 9b). NHE1 overexpressing cells, as opposed to the mock control, secreted a substantial amount of MMP3. MMP3 secretion was reduced in cariporide (HOE642)-treated cells, indicating that both NHE1 expression and its activity promote MMP3 secretion.

\section{Discussion}

The main purpose of the present study was to check a possible relationship between NHE1 expression, the cortical cell stiffness of human melanoma (MV3) cells and their ability to invade a defined collagen I substrate. We found that the overexpression of NHE1 leads to an increase in cortical stiffness without affecting the bulk stiffness (Fig. 2). This increase in cortical stiffness is accompanied, if not even caused, by a rearrangement of cortical F-actin (Fig. 3). At the same time, although showing an increase in cortical stiffness, the NHE1 overexpressing cells are significantly more invasive (Fig. 7). This increase in invasiveness is probably mediated by an elevated MMP3 secretion and activity (Figs. 8, 9). Since NHE1, especially its activity,

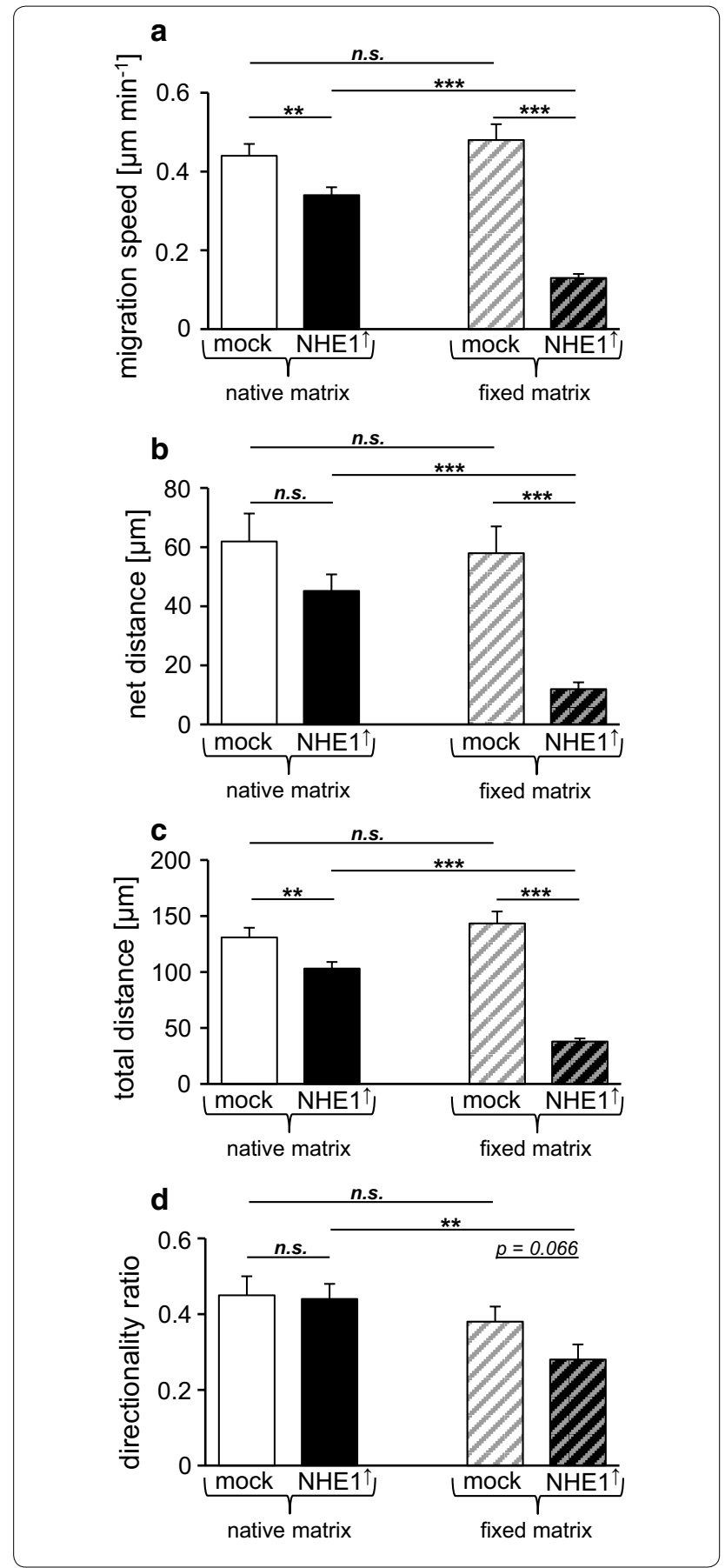

stimulates not only the expression of several MMPs at both mRNA and protein level but also their $\mathrm{pH}$ dependent activity [32-34], we minimized the effects of NHE1-mediated MMP activity by utilizing aldehydefixed matrices. The cells are hardly able to invade such a fixed collagen substrate. In those cells that do transmigrate across the fixed substrate, the NHE1 inhibitor cariporide (HOE642) has no effect suggesting that 
Table 1 Effects of matrix fixation and NHE1 expression on cell migration and morphology

\begin{tabular}{|c|c|c|c|c|}
\hline \multirow{2}{*}{$\begin{array}{l}\text { Matrix } \\
\text { NHE1 expression }\end{array}$} & \multicolumn{2}{|l|}{ Native } & \multicolumn{2}{|l|}{ Fixed } \\
\hline & Mock control $(\mathrm{n}=30 ; N=5)$ & Overexpressed $(\mathrm{n}=40 ; N=3)$ & Mock control $(n=40 ; N=3)$ & $\begin{array}{l}\text { Overexpressed } \\
(\mathrm{n}=41 ; N=3)\end{array}$ \\
\hline Speed $\left[\mu \mathrm{m} \mathrm{min}{ }^{-1}\right]$ & $0.44 \pm 0.03$ & $0.034 \pm 0.02$ & $0.48 \pm 0.04$ & $0.13 \pm 0.01$ \\
\hline Net distance $[\mu \mathrm{m}]$ & $61.92 \pm 9.42$ & $45.17 \pm 5.6$ & $57.92 \pm 9.07$ & $11.93 \pm 2.33$ \\
\hline Total distance $[\mu \mathrm{m}]$ & $130.92 \pm 8.61$ & $103.12 \pm 5.78$ & $143.37 \pm 10.67$ & $37.84 \pm 2.83$ \\
\hline Directionality & $0.45 \pm 0.05$ & $0.44 \pm 0.04$ & $0.38 \pm 0.04$ & $0.28 \pm 0.04$ \\
\hline Structural index & $0.43 \pm 0.03$ & $0.5 \pm 0.02$ & $0.3 \pm 0.01$ & $0.42 \pm 0.02$ \\
\hline Area $\left[\mu \mathrm{m}^{2}\right]$ & $888 \pm 112$ & $1115 \pm 84$ & $1251 \pm 78$ & $1298 \pm 94$ \\
\hline
\end{tabular}

Data are shown as mean \pm SEM For $p$ values and further information, please see text

NHE1 activity-dependent processes are not crucial under these conditions (Fig. 7). Sound actin dynamics, however, are necessary, as cytochalasin D, an inhibitor of actin polymerization, impedes transmigration across a fixed substrate almost completely.

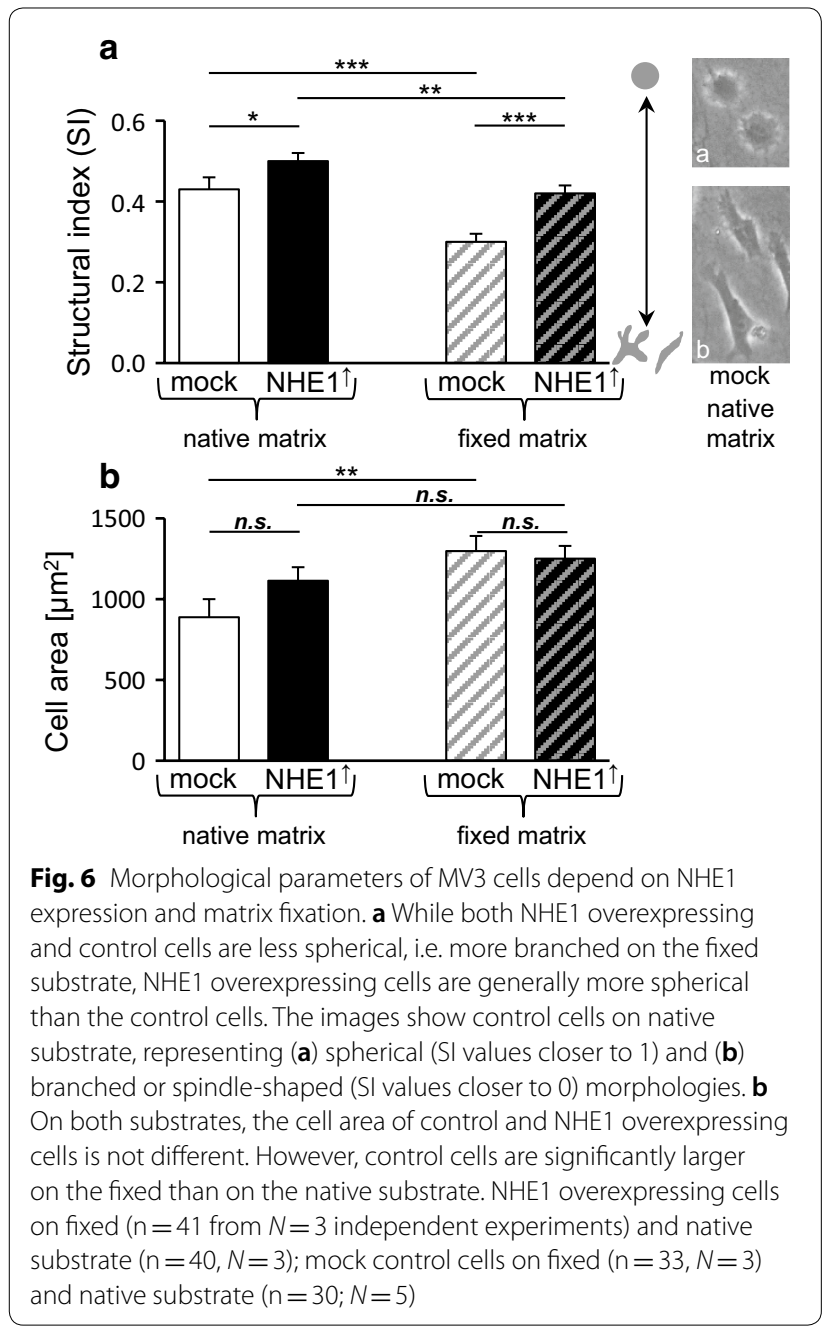

In the present migration experiments, NHE1 overexpression causes significant cell rounding and slowdown (Figs. 5, 6). The observation that cell rounding accompanied by a decrease in 2D motility correlates with an increased invasiveness is consistent with the finding that murine melanoma (B16V) cells spread and migrate on a basement membrane-like matrix, whereas they hardly migrate on, and instead invade, a dermis-like matrix [35].

NHE1 acts as a structural anchor for actin filaments by directly binding actin binding proteins of the ERM family [9]. Usually, an N-terminal domain of an activated, i.e. phosphorylated, ERM protein binds to a positively charged residue in the cytoplasmic tail of a transmembrane protein, such as NHE1, while its C-terminal domain binds actin filament(s). Thus, ERM proteins cross-link the plasma membrane to the underlying cortical actin [36]. One member of the ERM family is moesin [37]. The activation of moesin upon entry into mitosis is required for cell rounding accompanied by an increase in cortical rigidity [38]. This finding is in line with the present observation that an overexpression of NHE1, one of the binding partners of the ERM family, causes an increase in cortical stiffness associated with a rearrangement of the cortical F-actin.

In addition to its function as a mere structural element, NHE1 may affect cortical stiffness also by its activity. Comparing the cortical stiffness of completely untreated NHE1 overexpressing MV3 cells with that of cariporide-treated NHE1 overexpressing cells does not reveal a significant difference. However, the cortical stiffness of cells treated with the solvent DMSO alone is slightly higher than that of cells treated with cariporide solved in DMSO. Without any doubt, DMSO has a strong impact on the plasma membrane. It induces membrane thinning, increases the fluidity of the membrane's hydrophobic core and, at higher concentrations, creates transient water pores in the membrane [39]. DMSO as a component of freezing media causes a significant 

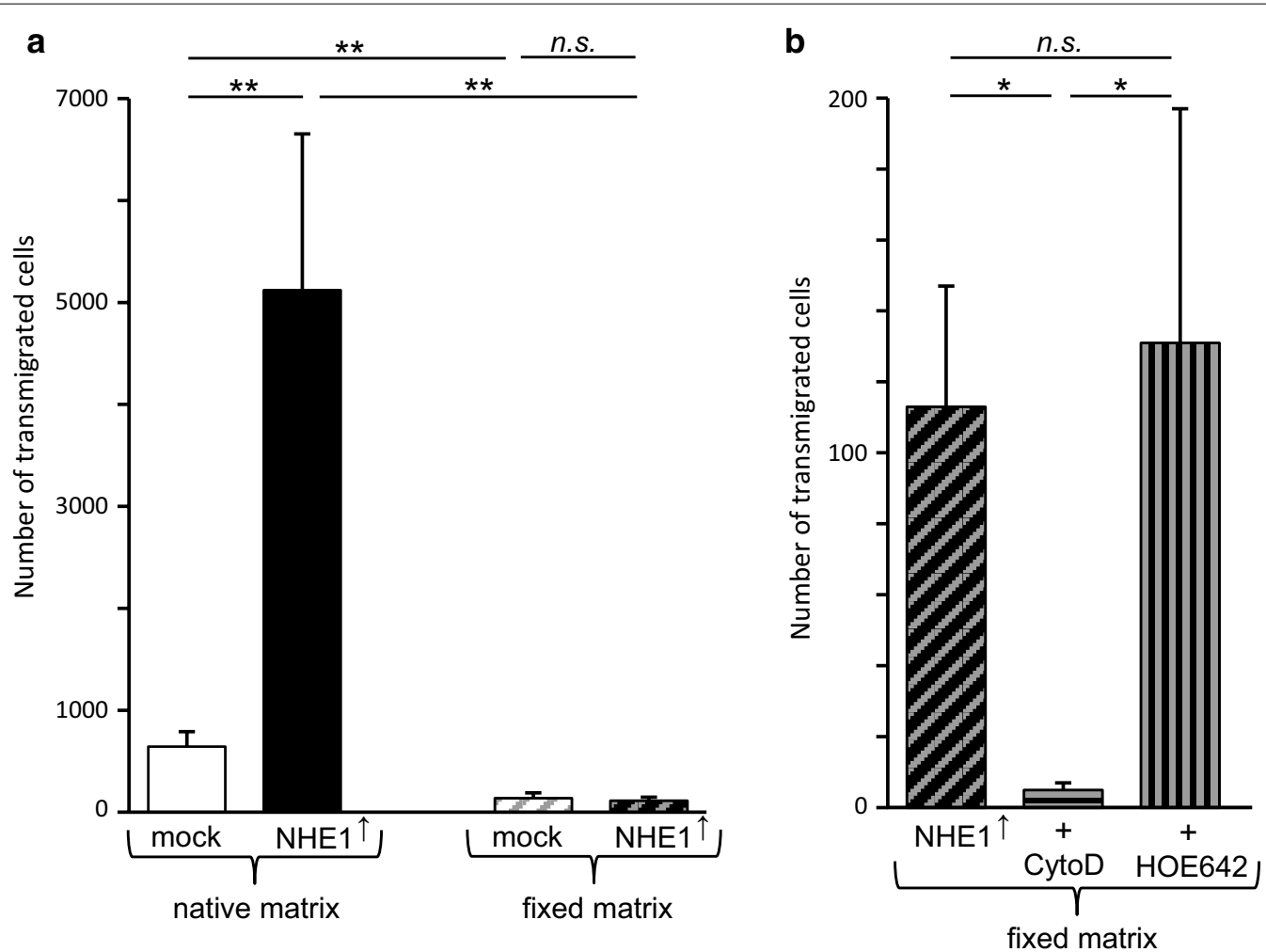

Fig. 7 In Boyden chamber assays, MV3 cell invasion is affected by NHE1 expression, matrix fixation and actin cytoskeleton. a When seeded on a native matrix, the number of transmigrated cells is considerably higher in NHE1 overexpressing ( $N=3$ with $n=6$ filter inserts/wells per experiment) than in control cells $(N=3, n=6)$. The number of cells crossing a fixed matrix is strongly reduced and does not differ significantly between NHE1 overexpressing $(n=20, N=5)$ and control cells $(n=14, N=4)$. b On a fixed substrate, NHE1 inhibition by cariporide (HOE642) has no effect on the transmigration of NHE1 overexpressing MV3 cells $(n=15, N=3)$. Inhibition of actin dynamics with cytochalasin D blocks invasion of NHE1 overexpressing cells almost completely $(n=11, N=3)$

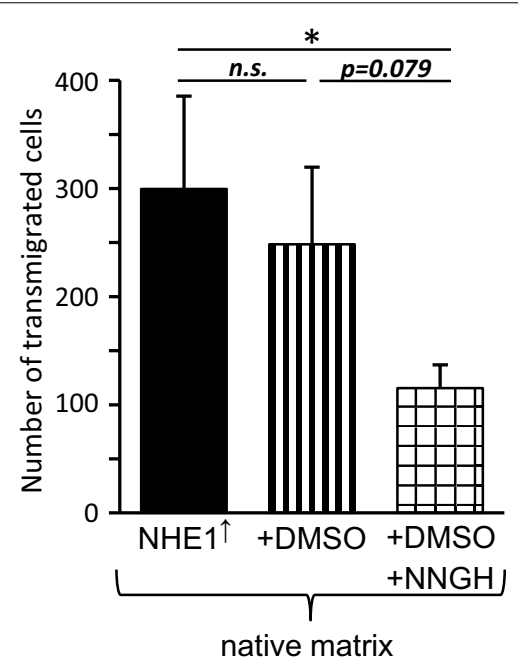

Fig. 8 Invasion of NHE1 overexpressing MV3 cells depends on MMP activity. In presence of the MMP inhibitor NNGH in DMSO, the number of cells crossing a native substrate is clearly reduced $(n=6$ filter inserts from $N=3$ independent experiments each) increase in the stiffness of mouse embryonic fibroblasts [40]. Moreover, DMSO increases the membrane permeability for $\mathrm{K}^{+}$in a dose-dependent manner in monocytes (THP-1 cells [41]). The diameter of a hydrated $\mathrm{K}^{+}$ion is assumed to be $\sim 0.133 \mathrm{~nm}$ while that of a hydrated $\mathrm{Na}^{+}$ ion comes to $\sim 0.5 \mathrm{~nm}(0.095 \mathrm{~nm}$ non-hydrated ionic radius $+\sim 0.4 \mathrm{~nm}$ hydration shell [42]). Nonetheless, it could be possible that DMSO increases the membrane permeability for $\mathrm{Na}^{+}$as well. The DMSO-mediated increase in the membrane permeability for water and/ or $\mathrm{Na}^{+}$would lead to an osmotic swelling resulting in a higher stiffness. Provided that unfolding membrane reservoirs are not available, osmotic swelling would cause the cell membrane to stiffen [43] while, at the same time, the cortical actin cytoskeleton would behave like an expanding sponge and enhance the stiffening [44]. In the present study, cariporide (HOE642) in presence of its solvent DMSO reduces the cortical stiffness. At this point, we are not able to determine to what extent (i) a decrease in the number of $\mathrm{Na}^{+}$ions imported by NHE1 and thus osmotic shrinkage $[45,46]$, (ii) a decrease in cytosolic $\mathrm{pH}$ 
a

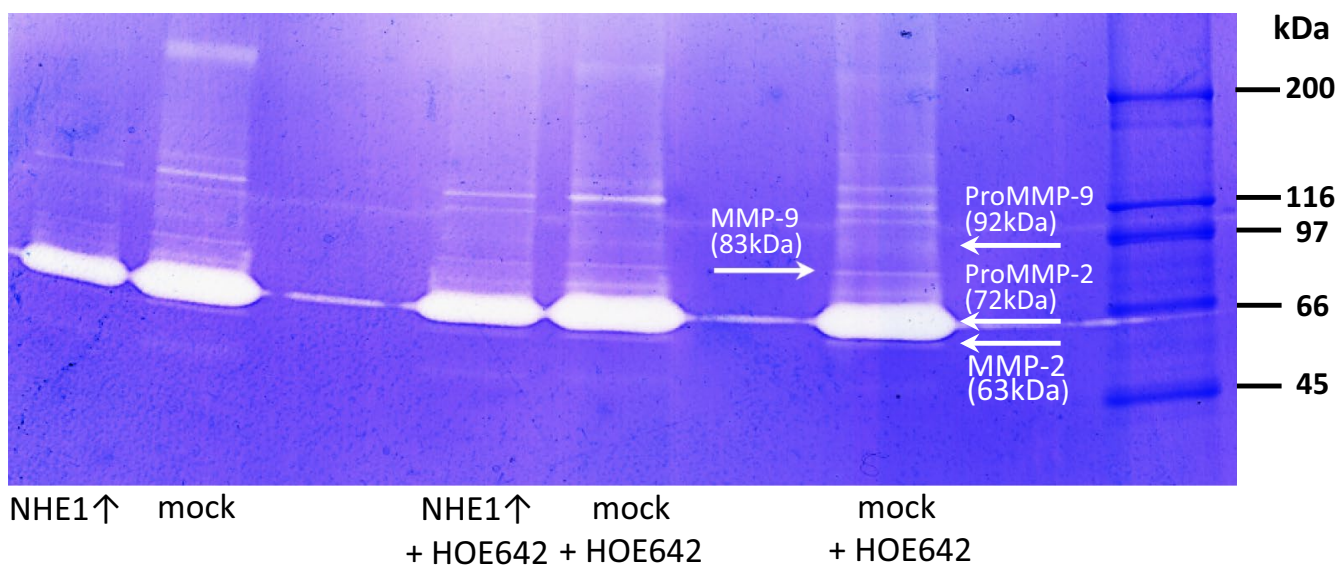

b

Immuno blot

Total protein loading control
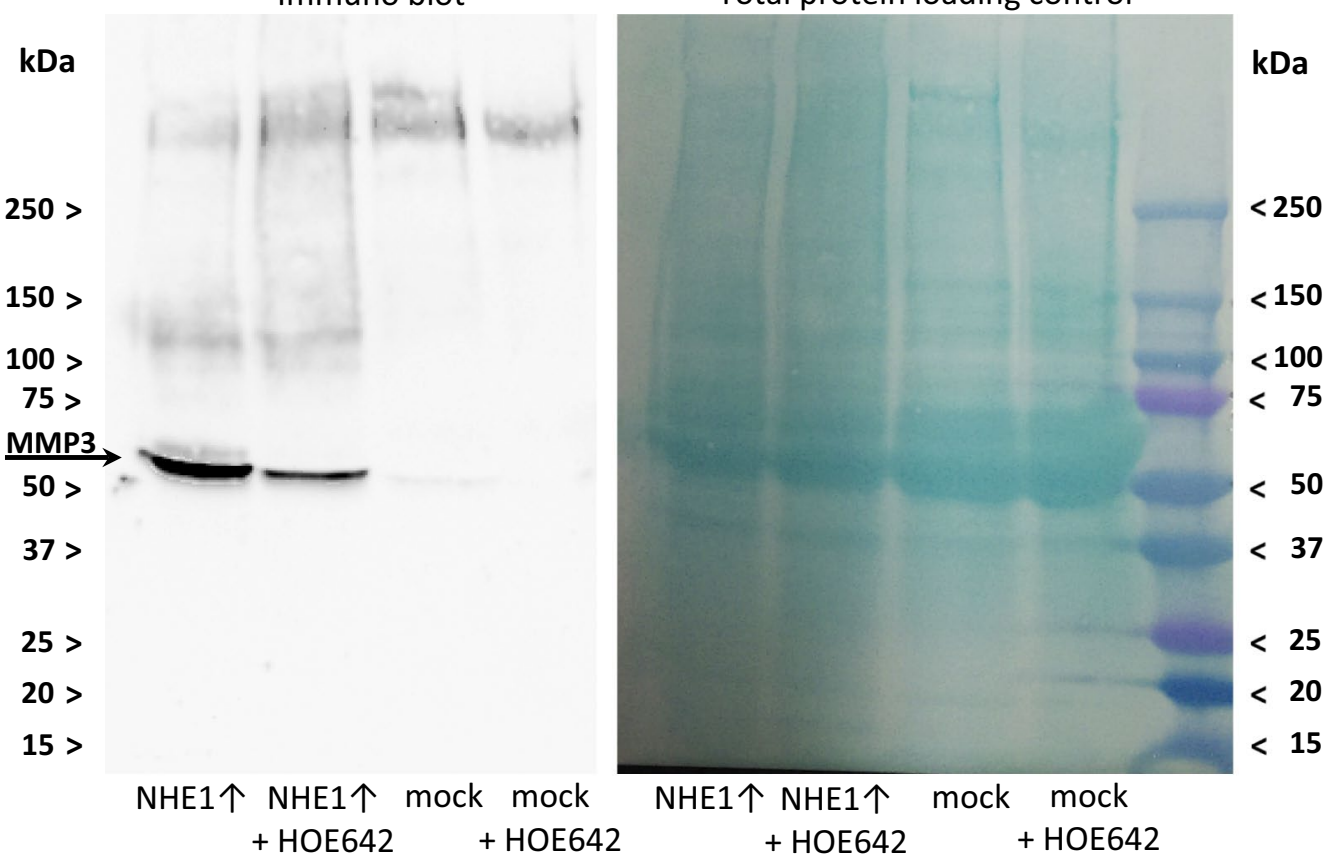

Fig. 9 NHE1 overexpression promotes MMP3 secretion in MV3 cells. Supernatants of cell cultures were analyzed. a Gelatin degradation assays indicate slight MMP9 and strong pro-MMP9 activity under all conditions examined (NHE1 overexpression, mock control, NHE1 inhibition with cariporide (HOE642)), $(\mathrm{N}=3)$. b Immunoblot analysis shows a strong secretion of MMP3 ( $54 \mathrm{kDa}$ ) in NHE1 overexpressing cells which can be reduced by cariporide (HOE642) $(N=4)$

[47] or (iii) other factors such as $\mathrm{pH}$-dependent signaling [48] contribute to the cariporide-induced, slight decrease in cortical stiffness.

The restructuring of the cortical actin meshwork accompanied by an increase in cortical stiffness (Figs. 2, 3) most likely modulates both the architecture including the lipid packing [49] and the composition of the plasma membrane [50] of NHE1 overexpressing cells. This could then modulate enzymatic activities [51] and catalyze the conversion of sphingolipids such as ceramide, sphingomyelins or glycosphingolipids [52, 53]. For instance, the acid sphingomyelinase catalyzes the cleavage of sphingomyelin to produce ceramide and phosphorylcholine, and the sphingomyelin deacylase catalyzes the hydrolysis of $\mathrm{N}$-acyl-sphingosylphosporylcholine leading to the generation of a fatty acid and sphingosylphosphorylcholine (SPC). SPC induces the expression and secretion of MMP3 [54]. In the present Western blot analysis, 
NHE1 overexpression in MV3 cells is accompanied by an increase in MMP3 secretion. Normally, at physiological $\mathrm{pH}$ values of $\sim 7.4$, NHE1 activity and thus the number of $\mathrm{H}^{+}$delivered to the cell surface are rather low. However, not only the acid sphingomyelinase [55] but also the sphingomyelin deacylase [56] show their maximum activities at rather low $\mathrm{pH}$ values of $\mathrm{pH} \sim 5.0$. Since we found an increased MMP3 secretion in the NHE1 overexpressing cells and because in a wide variety of cancers including melanoma cells NHE1 activity is considerably elevated $[1,3,57,58]$, it is conceivable that the number of $\mathrm{H}^{+}$ions released at the cell surface may be high enough to sufficiently stimulate the sphingomyelin-converting enzymes (and through SPC indirectly MMP3) even though neither the proper nor a large-area $\mathrm{pH}$ optimum is reached. Immunoblotting the media revealed that NHE1 overexpressing MV3 cells do secrete more MMP3 depending on NHE1 activity (Fig. 9b). Furthermore, MMP3 as activator of collagenases [30] most likely plays a crucial role because MMP inhibition by NNGH leads to a distinct decrease in transmigration across native matrices (Fig. 8).

Both expression and activity of NHE1 affect the cell cycle and correlate with proliferation [59, 60]. Therefore, the increase in the number of MV3 cells that invade native matrices could be partially due to an increased proliferation associated with NHE1 overexpression (Fig. 7a). On the other hand, this assumption should hold true also for NHE1 overexpressing cells invading a fixed matrix. But there is no difference in transmigration between NHE1 overexpressing and control cells.

Fixation of extracellular matrices with glutaraldehyde modifies their micro-elastic properties and leads to a substantial increase in matrix stiffness [61]. The matrix stiffness modulates cell behavior [62], induces malignant phenotypes [63] and can trigger epithelial-mesenchymal transition (EMT [64]). In fact, the MV3 cells are more spread and less spherical on a glutaraldehyde-fixed compared to a native collagen type I substrate. While unchanged in control cells, cell motility of NHE1 overexpressing MV3 cells is significantly decreased on a fixed substrate (Fig. 5). Albeit this is probably caused by the absence of $\mathrm{H}^{+}$-dependent events such as modulation of $\mathrm{pH}$-sensitive cell/matrix interactions [6] and MMP activity [34], a certain impact of the matrix rigidity on cell motility cannot at all be excluded and could also affect transmigration across the fixed substrate. In a threedimensional setting such as the Boyden chamber/transmigration assay it is hardly possible to precisely dissect to what extent the different physiological and biophysical parameters affect invasiveness.

\section{Conclusion}

Given the entire data set, we conclude that in MV3 cells, NHE1 overexpression causes a rearrangement of F-actin at the cell cortex associated with an increase in cortical stiffness. This rearrangement in F-actin is likely to rely on the $\mathrm{pH}$-sensitive and thus NHE1-dependent interaction between cortactin and cofilin [65]. Despite their higher cortical stiffness NHE1 overexpressing cells are considerably more invasive on a collagen type I substrate, most likely due to increases in MMP3 secretion and activity. This is in line with the proposed concerted roles of cortactin and F-actin in regulating the secretion of proteases [66]. In addition, the link between NHE1 overexpression and MMP3 secretion may also include the architecture and composition of the plasma membrane and should be analyzed in future studies. In the long term and with simultaneous consideration of the (cellular) lipid metabolism, the relationship between the expressions of NHE1 and MMP3 may gain in importance for the development of anticancer drugs.

\section{Abbreviations \\ B16V: murine melanoma cell line; DMSO: dimethyl sulfoxide; ECM: extracel- lular matrix; ERM: ezrin, radixin, moesin protein family; EMT: epithelial-to- mesenchymal transition; HOE642: cariporide (NHE1 inhibitor); MMP: matrix metalloproteinase; MV3: human melanoma cell line; $\mathrm{NHE1}$ : $\mathrm{Na}^{+} / \mathrm{H}^{+}$exchanger 1; NNGH: $N$-isobutyl-N-(4-methoxyphenylsulfonyl)glycyl hydroxamic acid; PBS: phosphate buffered saline; PVDF: polyvinylidene difluoride; SDS: sodium dodecyl sulfate; SPC: sphingosylphosphorylcholine; TBS-T: Tris-buffered saline with Tween20; Tris: Tris(hydroxymethyl)-aminomethane.}

\section{Acknowledgements \\ The authors would like to thank Dr. Jochen Seebach and Prof. Dr. Hans- Joachim Schnittler from the Institute of Anatomy and Vascular Biology in Münster, Germany, for helping with optimizing the matrix fixation protocol. This work was supported by a German Cancer Aid Grant (\#111262) to CS.}

\section{Authors' contributions}

FF generated the cell clones and delivered the fundamental idea. DK designed and performed the vast majority of (all types of) experiments. IL and VH supervised and performed AFM experiments. SN performed migration assays and actin staining. RD designed, supervised and performed zymography assays and MMP blots. CS designed and supervised experiments and wrote the manuscript. All authors read and approved the final manuscript.

\section{Funding}

This work was supported by a German Cancer Aid Grant (\#111262) to CS.

\section{Availability of data and materials}

The datasets used and/or analysed during the current study are available from the corresponding author on reasonable request.

Ethics approval and consent to participate

Not applicable.

\section{Consent for publication}

Not applicable.

\section{Competing interests}

The authors declare that they have no competing interests. 


\begin{abstract}
Author details
${ }_{1}^{1}$ Institute of Physiology II, University of Münster, Robert-Koch-Str. 27b, 48149 Münster, Germany. ${ }^{2}$ Department of Oncology and Hematology, University Hospital of Münster, Albert-Schweitzer-Campus 1, 48149 Münster, Germany. ${ }^{3}$ Institute of Animal Physiology, University of Münster, Schlossplatz 8, 48143 Münster, Germany. ${ }^{4}$ Institute of Physiological Chemistry and Pathobiochemistry, University of Münster, Waldeyer-Str. 15, 48149 Münster, Germany. ${ }^{5}$ Department of Gastroenterology, Hannover Medical School, Carl-Neuberg-Str. 1, 30625 Hannover, Germany.
\end{abstract}

Received: 21 August 2019 Accepted: 1 November 2019 Published online: 09 November 2019

\section{References}

1. Stock C, Pedersen SF. Roles of $\mathrm{pH}$ and the $\mathrm{Na}^{+} / \mathrm{H}^{+}$exchanger $\mathrm{NHE} 1$ in cancer: from cell biology and animal models to an emerging translational perspective? Semin Cancer Biol. 2017;43:5-16.

2. Counillon L, Bouret $Y$, Marchiq I, Pouysségur J. $\mathrm{Na}^{+} / \mathrm{H}^{+}$antiporter (NHE1) and lactate/ $\mathrm{H}^{+}$symporters (MCTs) in $\mathrm{pH}$ homeostasis and cancer metabolism. Biochim Biophys Acta. 2016;1863:2465-80.

3. Cardone RA, Casavola V, Reshkin SJ. The role of disturbed pH dynamics and the $\mathrm{Na}^{+} / \mathrm{H}^{+}$exchanger in metastasis. Nat Rev Cancer. 2005;5:786-95.

4. Reshkin SJ, Bellizzi A, Caldeira S, Albarani V, Malanchi I, Poignee M, AlunniFabbroni M, Casavola V, Tommasino M. Na ${ }^{+} / \mathrm{H}^{+}$exchanger-dependent intracellular alkaliniziation is an early event in malignant transformation and plays an essential role in the development of subsequent transformation-associated phenotypes. FASEB J. 2000;14:2185-97.

5. Harguindey S, Orive G, Luis Pedraz J, Paradiso A, Reshkin SJ. The role of pH dynamics and the $\mathrm{Na}^{+} / \mathrm{H}^{+}$antiporter in the etiopathogenesis and treatment of cancer: two faces of the same coin-one single nature. Biochim Biophys Acta. 2005;1756:1-24.

6. Ludwig FT, Schwab A, Stock C. The $\mathrm{Na}^{+} / \mathrm{H}^{+}$exchanger (NHE1) generates pH nanodomains at focal adhesions. J Cell Physiol. 2013;228:1351-8.

7. Kato Y, Ozawa S, Miyamoto C, Maehata Y, Suzuki A, Maeda T, Baba Y. Acidic extracellular environment and cancer. Cancer Cell Int. 2013:13:89.

8. Stock C, Schwab A. Ion channels and transporters in metastasis. Biochim Biophys Acta. 2014;1848:2638-46.

9. Baumgartner $\mathrm{M}$, Patel $\mathrm{H}$, Barber DL. $\mathrm{Na}^{+} / \mathrm{H}^{+}$exchanger NHE1 as plasma membrane scaffold in the assembly of signaling complexes. Am J Physiol. 2004;287:C844-50.

10. Denker SP, Huang DC, Orlowski J, Furthmayr H, Barber DL. Direct binding of the $\mathrm{Na}-\mathrm{H}$ exchanger NHE1 to ERM proteins regulates the cortical cytoskeleton and cell shape independently of $\mathrm{H}^{+}$translocation. Mol Cell. 2000;6:1425-36

11. Denker SP, Barber DL. Cell migration requires both ion translocation and cytoskeletal anchoring by the Na-H exchanger NHE1. J Cell Biol. 2002;159:1087-96

12. Svitkina T. The actin cytoskeleton and actin-based motility. Cold Spring Harb Perspect Biol. 2018;10:a018267.

13. Grimm KB, Oberleithner H, Fels J. Fixed endothelial cells exhibit physiologically relevant nanomechanics of the cortical actin web. Nanotechnology. 2014;25:215101.

14. Callies C, Fels J, Liashkovich I, Kliche K, Jeggle P, Kusche-Vihrog K, Oberleithner $\mathrm{H}$. Membrane potential depolarization decreases the stiffness of vascular endothelial cells. J Cell Sci. 2011;124:1936-42.

15. Liu Y-J, Le Berre M, Lautenschlaeger F, Maiuri P, Callan-Jones A, Heuzé M, Takaki T, Voituriez R, Piel M. Confinement and low adhesion induce fast amoeboid migration of slow mesenchymal cells. Cell. 2015;160:660-73.

16. Ruprecht V, Wieser S, Callan-Jones A, Smutny M, Morita H, Sako K, Barone V, Ritsch-Marte M, Sixt M, Voituriez R, Heisenberg C-P. Cortical contractility triggers a stochastic switch to fast amoeboid cell motility. Cell. 2015;160:673-85.

17. Charras G, Paluch E. Blebs lead the way. How to migrate without lamellipodia. Nat Rev Mol Cell Biol. 2008;9:730-6.

18. Swaminathan V, Mythreye K, O'Brien ET, Berchuck A, Blobe GC, Superfine R. Mechanical stiffness grades metastatic potential in patient tumor cells and in cancer cell lines. Cancer Res. 2011:71:5075-80.
19. Xu W, Mezencev R, Kim B, Wang L, McDonald J, Sulchek T. Cell stiffness is a biomarker of the metastatic potential of ovarian cancer cells. PLoS ONE. 2012;7:e46609.

20. Lekka M, Laidler P, Gil D, Lekki K, Stachura Z, Hrynkiewicz AZ. Elasticity of normal and cancerous human bladder cells studied by scanning force microscopy. Eur Biophys J. 1999;28:312-6.

21. van Muijen GN, Jansen KF, Cornelissen IM, Smeets DF, Beck JL, Ruiter DJ. Establishment and characterization of a human melanoma cell line (MV3) which is highly metastatic in nude mice. Int J Cancer. 1991;48:85-91

22. Frontzek F, Nitzlaff S, Horstmann M, Schwab A, Stock C. Functional interdependence of NHE1 and merlin in human melanoma cells. Biochem Cell Biol. 2014;92:430-540.

23. Dimitriadis EK, Horkay F, Maresca J, Kachar B, Chadwick RS. Determination of elastic moduli of thin layers of soft material using the atomic force microscope. Biophys J. 2002;82:2798-810.

24. Carl P, Schillers H. Elasticity measurement of living cells with an atomic force microscope: data acquisition and processing. Pflugers Arch. 2008;457:551-9.

25. Dieterich P, Klages R, Preuss R, Schwab A. Anomalous dynamics of cell migration. Proc Natl Acad Sci USA. 2008;105:459-63.

26. Harguindey S, Arranz JL, Polo Orozco JD, Rauch C, Fais S, Cardone RA, Reshkin SJ. Cariporide and other new and powerful NHE1 inhibitors as potentially selective anticancer drugs - an integral molecular/biochemi$\mathrm{cal} / \mathrm{metabolic/clinical} \mathrm{approach} \mathrm{after} \mathrm{one} \mathrm{hundred} \mathrm{years} \mathrm{of} \mathrm{cancer}$ research. J Transl Med. 2013;11:282.

27. Busco G, Cardone RA, Greco MR, Bellizzi A, Colella M, Antelmi E, Mancini MT, Dell'Aquila ME, Casavola V, Paradiso A, Reshkin SJ. NHE1 promotes invadopodial ECM proteolysis through acidification of the peri-invadopodial space. FASEB J. 2010;24:3903-15.

28. Hofschröer , Koch KA, Ludwig FT, Friedl P, Oberleithner H, Stock C, Schwab A. Extracellular protonation modulates cell-cell interaction mechanics and tissue invasion in human melanoma cells. Sci Rep. 2017;7:42369

29. Greco MR, Antelmi E, Busco G, Guerra L, Rubino R, Casavola V, Reshkin $\mathrm{SJ}$, Cardone RA. Protease activity at invadopodial focal digestive areas is dependent on NHE1-driven acidic pH. Oncol Rep. 2014;31:940-6.

30. Johnson LL, Dye R, Hupe DJ. Matrix metalloproteinases. Curr Opin Chem Biol. 1998;2:466-71.

31. Ala-aho R, Kähäri VM. Collagenases in cancer. Biochimie. 2005;87:273-86.

32. Lin Y, Chang G, Wang J, Jin W, Wang L, Li H, Ma L, Li Q, Pang T. NHE1 mediates MDA-MB-231 cells invasion through the regulation of MT1-MMP. Exp Cell Res. 2011;317:2031-40.

33. Lin Y, Wang J, Jin W, Wang L, Li H, Ma L, Li Q, Pang T. NHE1 mediates migration and invasion of HeLa cells via regulating the expression and localization of MT1-MMP. Cell Biochem Funct. 2012;30:41-6.

34. Stock C, Cardone RA, Busco G, Krähling H, Schwab A, Reshkin SJ. Protons extruded by NHE1: digestive or glue? Eur J Cell Biol. 2008;87:591-9.

35. Vahle AK, Domikowsky B, Schwöppe C, Krähling H, Mally S, Schäfers M, Hermann S, Shahin V, Haier J, Schwab A, Stock C. Extracellular matrix composition and interstitial pH modulate NHE1-mediated melanoma cell motility. Int J Oncol. 2014;44:78-90.

36. Bretscher A, Edwards K, Fehon RG. ERM proteins and merlin: integrators at the cell cortex. Nat Rev Mol Cell Biol. 2002;3:586-99.

37. Pearson MA, Reczek D, Bretscher A, Karplus PA. Structure of the ERM protein moesin reveals the FERM domain fold masked by an extended actin binding tail domain. Cell. 2000;101:259-70.

38. Kunda P, Pelling AE, Liu T, Baum B. Moesin controls cortical rigidity, cell rounding, and spindle morphogenesis during mitosis. Curr Biol. 2008;18:91-101.

39. Gurtovenko AA, Anwar J. Modulating the structure and properties of cell membranes. The molecular mechanism of action of dimethyl sulfoxide. J Phys Chem B. 2007;111:10453-60.

40. Golan M, Jelinkova S, Kratochvílová I, Skládal P, Pešl M, RotrekI V, Pribyl J. AFM monitoring the influence of selected cryoprotectants on regeneration of cryopreserved cells mechanical properties. Front Physiol. 2018;9:804.

41. Xiang Y, Zhao MM, Sun S, Guo XL, Wang Q, Li SA, Lee WH, Zhang Y. A high concentration of DMSO activates caspase-1 by increasing the cell membrane permeability of potassium. Cytotechnology. 2018;70:313-20. 
42. Degrève L, Vechi M, Quintale C Jr. The hydration structure of the $\mathrm{Na}^{+}$and $\mathrm{K}^{+}$ions and the selectivity of their ionic channels. Biochim Biophys Acta Bioenergy. 1996;1274:149-56.

43. Ayee MAA, Levitan I. Membrane stiffening in osmotic swelling: analysis of membrane tension and elastic modulus. Curr Top Membr. 2018;81:97-123.

44. Chao PC, Sivaselvan M, Sachs F. Cytoskeletal contribution to cell stiffness due to osmotic swelling; extending the Donnan equilibrium. Curr Top Membr. 2018;81:83-96.

45. Pedersen SF, Hoffmann EK. Possible interrelationship between changes in F-actin and myosin II, protein phosphorylation, and cell volume regulation in Ehrlich ascites tumor cells. Exp Cell Res. 2002;277:57-73.

46. Lambert IH, Hoffmann EK, Pedersen SF. Cell volume regulation: physiology and pathophysiology. Acta Physiol. 2008;194:255-82.

47. Chatterjee S, Schmidt S, Pouli S, Honisch S, Alkahtani S, Stournaras C, Lang F. Membrane androgen receptor sensitive $\mathrm{Na}^{+} / \mathrm{H}^{+}$exchanger activity in prostate cancer cells. FEBS Lett. 2014;588:1571-9.

48. White KA, Grillo-Hill BK, Esquivel M, Peralta J, Bui VN, Chire I, Barber DL. $\beta$-Catenin is a $\mathrm{pH}$ sensor with decreased stability at higher intracellular pH. J Cell Biol. 2018;217:3965-76.

49. Fritzsche M, Li D, Colin-York H, Chang VT, Moeendarbary E, Felce JH, Sezgin E, Charras G, Betzig E, Eggeling C. Self-organizing actin patterns shape membrane architecture but not cell mechanics. Nat Commun. 2016:8:14347.

50. Beard J, Attard GS, Cheetham MJ. Integrative feedback and robustness in a lipid biosynthetic network. J R Soc Interface. 2008;5:533-43.

51. Dymond M. Mammalian phospholipid homeostasis: evidence that membrane curvature elastic stress drives homeoviscous adaptation in vivo. J R Soc Interface. 2016;13:20160228.

52. Busik JV, Esselman WJ, Reid GE. Examining the role of lipid mediators in diabetic retinopathy. Clin Lipidol. 2012;7:664-75.

53. Jenkins RW, Canals D, Hannun YA. Roles and regulation of secretory and Iysosomal acid sphigomyelinases. Cell Signal. 2009;21:836-46.

54. Kim HJ, Kang GJ, Kim EJ, Park MK, Byun HJ, Nam S, Lee H, Lee CH. Novel effects of sphingosylphosphorylcholine on invasion of breast cancer: involvement of matrix metalloproteinase-3 secretion leading to WNT activation. Biochim Biophys Acta. 2016;1862:1533-43.

55. Goni FM, Alonso A. Sphingomyelinases: enzymology and membrane activity. FEBS Lett. 2002;531:38-46.

56. Higuchi K, Hara J, Okamoto R, Kawashima M, Imokawa G. The skin of atopic dermatitis patients contains a novel enzyme, glucosylceramide sphingomyelin deacylase, which cleaves the $\mathrm{N}$-acyl linkage of sphingomyelin and glucosylceramide. Biochem J. 2000;350:747-56.
57. Karki P, Li X, Schrama D, Fliegel L. B-Raf associates with and activates the NHE1 isoform of the $\mathrm{Na}^{+} / \mathrm{H}^{+}$exchanger. J Biol Chem. 2011;286:13096-105.

58. Stock C, Ludwig FT, Schwab A. Is the multifunctional $\mathrm{Na}^{+} / \mathrm{H}^{+}$exchanger isoform 1 a potential therapeutic target in cancer? Curr Med Chem. 2012;19:647-60.

59. Flinck M, Kramer SH, Schnipper J, Andersen AP, Pedersen SF. The acidbase transport proteins NHE1 and NBCn1 regulate cell cycle progression in human breast cancer cells. Cell Cycle. 2018;17:1056-67.

60. Sanhueza C, Araos J, Naranjo L, Toledo F, Beltran AR, Ramirez MA, Gutierrez J, Pardo F, Leiva A, Sobrevia L. Sodium/proton exchanger isoform 1 regulates intracellular $\mathrm{pH}$ and cell proliferation in human ovarian cancer. Biochim Biophys Acta Mol Basis Dis. 2017;1863:81-91.

61. Soucy PA, Werbin J, Heinz W, Hoh JH, Romer LH. Microelastic properties of lung cell-derived extracellular matrix. Acta Biomater. 2011;7:96-105.

62. Handorf AM, Zhou Y, Halanski MA, Li W-J. Tissue stiffness dictates development, homeostasis, and disease progression. Organogenesis. 2015;11:1-15

63. Chaudhuri O, Koshy ST, Branco da Cunha C, Shin JW, Verbeke CS, Allison $\mathrm{KH}$, Mooney DJ. Extracellular matrix stiffness and composition jointly regulate the induction of malignant phentoypes in mammary epithelium. Nat Mater. 2014;13:970-8.

64. Rice AJ, Cortes E, Lachowski D, Cheung BCH, Karim SA, Morton JP, Del Rio Hernandez A. Matrix stiffness induces epithelial-mesenchymal transition and promotes chemoresistance in pancreatic cancer cells. Oncogenesis. 2017;6:e352.

65. Magalhaes MA, Larson DR, Mader CC, Bravo-Cordero JJ, Gil-Henn H, Oser M, Chen X, Koleske AJ, Condeelis J. Cortactin phosphorylation regulates cell invasion through a $\mathrm{pH}$-dependent pathway. J Cell Biol. 2011;195:903-20.

66. Clark ES, Weaver AM. A new role for cortactin in invadopodia: regulation of protease secretion. Eur J Cell Biol. 2008;87:581-90.

\section{Publisher's Note}

Springer Nature remains neutral with regard to jurisdictional claims in published maps and institutional affiliations.
Ready to submit your research? Choose BMC and benefit from:

- fast, convenient online submission

- thorough peer review by experienced researchers in your field

- rapid publication on acceptance

- support for research data, including large and complex data types

- gold Open Access which fosters wider collaboration and increased citations

- maximum visibility for your research: over $100 \mathrm{M}$ website views per year

At BMC, research is always in progress.

Learn more biomedcentral.com/submissions 